УДК 621.644.2

И.Н. Никитина, А.В. Еремеев

НИУ МГСУ

ПЕРСПЕКТИВА

ПРИМЕНЕНИЯ

СТЕКЛОПЛАСТИКОВЫХ

ТРУБОПРОВОДОВ

ПРИ СТРОИТЕЛЬСТВЕ

И РЕКОНСТРУКЦИИ

ИНЖЕНЕРНЫХ

СЕТЕЙ

Приведен анализ основных характеристик стеклопластиковых трубопроводов, используемых при возведении систем водоснабжения и водоотведения. Показаны основные параметры и преимущества трубопроводов, используемых для реконструкции сетей методом микротоннелирования. Приведены варианты крепления стеклопластиковых трубопроводов с трубами из других материалов с помощью тройников и патрубков-накладок. Представлены варианты прокладки в особо сложных условиях под автомобильными и железными дорогами.

Ключевые слова: стеклопластиковый трубопровод, бестраншейные технологии, микротоннелирование, реновация, инженерные сети, давление, эксплуатация, коррозия, водоснабжение, водоотведение.

Модернизация и строительство новых инженерных сетей являются первостепенными задачами для бесперебойного обеспечения потребителей качественной питьевой водой и поддержания санитарного состояния застройки с использованием отвода сточных вод на очистные сооружения [1].

В современном строительстве практикуется использование технологий и материалов для трубопроводов систем водоснабжения и водоотведения, которые должны работать не менее 50 лет.

Широкое применение находят трубопроводы

ВЧШГ (из высокопрочного чугуна с шаровидным графитом), из различных пластмасс, а также композиционных материалов. В настоящей статье рассматриваются трубопроводы, изготавливаемые из стеклопластиков.

Стеклопластики - это специальный конструкционный материал, который включает в себя
I.N. Nikitina, A.V. Eremeev

MGSU

\section{POSSIBILITIES OF THE USE OF GRP PIPING IN THE CONSTRUCTION NETWORKS} ( optical fiber winding, which is carried out according to modern inenalional standards of quality. The basic raw materials - fiberglass and resin - are produced in Russia, but their production is Pipes, the manufacture of GRP pipes will increase. The experiin the areas of hot water supply allows concluding that they are able fhe weight of steel pipes (they are easily inpeople). It should be noted that the use of fiberglass pipes helps to sive protection against electrochemical corrosion. Piping made of fiberglass pipes can be designed as underground, above-ground with

Key words: fiberglass pipe, trenchless technology, microtunneling, renovation, utility systems, pressure, operation, corrosion, water supply, water disposal.

Modernization and construction of new engineering systems is a necessary task for regular provision of the consumers with high-quality drinking water and keeping sanitary state of buildings using wastewater disposal to treatment facilities [1].

In modern construction such technologies and materials are used for water supply pipelines, which should operate not less than 50 years.

Pipelines of high-strength cast iron with spherical graphite are widely used, as well as of different plastic and composite materials. The given article observes the pipelines produced of fiberglass.

Fiberglass is a special construction material, which includes two main com- 
два основных компонента: полимерную матрицу и армирующий наполнитель [2, 3].

Температурные режимы, режимы давления в сетях и долговечность данных трубопроводов напрямую зависят от различного типа смол, из которых они сделаны, а также от состава рабочей среды, в которой они будут работать и эксплуатироваться.

В отличие от пластмассовых трубопроводов, стеклопластиковые могут производиться больших размеров - вплоть до 3700 мм в диаметре. Их изготавливают по технологии намотки стекловолокна по современным международным стандартам качества. Основное сырье - стекловолокно и смолы - производятся в России, но в недостаточном объеме, поэтому его приходится докупать за рубежом, что делает изготовление трубопроводов более дорогостоящим (рис. 1). Необходимость прокладки трубопроводов больших диаметров, которые не сделать из пластмассовых труб, ведет к тому, что изготовление стеклопластиковых трубопроводов будет возрастать $[4,5]$. ponents: polymer matrix and reinforcing agent $[2,3]$.

Temperature modes, pressure conditions in networks and durability of these pipelines directly depend on different types of resins they are made of and the composition of the working environment.

Unlike plastic pipelines fiberglass ones may be produced in large sizes of up to $3700 \mathrm{~mm}$ in diameter. They are produced using the technology of optical fiber winding, which is carried out according to modern international standards of quality. The basic raw materials - fiberglass and resin - are produced in Russia, but their production is limited, so they are purchased abroad, which increases the cost of manufacture of this type of piping (fig. 1). The necessity of laying pipelines of large diameter, which cannot be made with plastic pipes, leads to the increase of GRP pipes manufacture increase $[4,5]$.

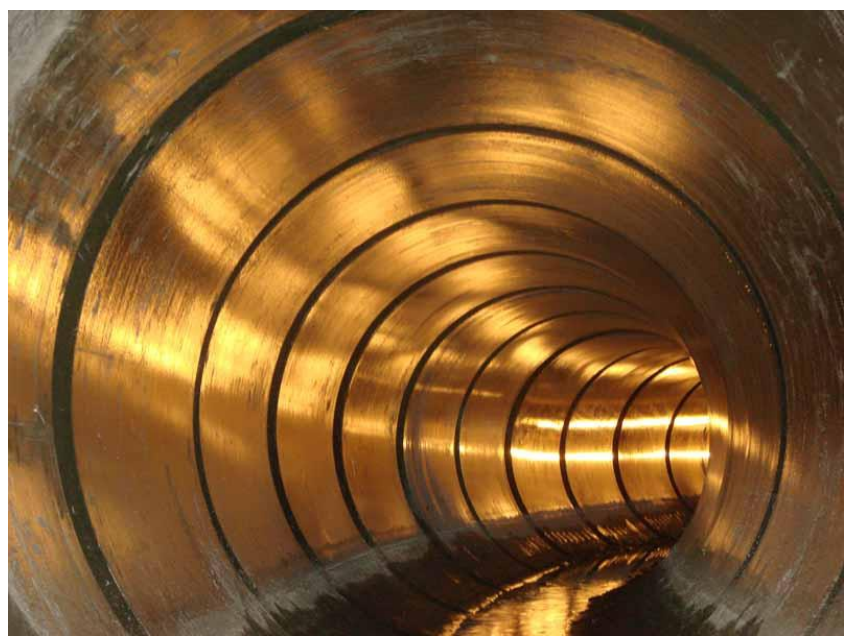

Рис. 1. Стеклопластиковая труба большого диаметра

Опыт прокладки и строительства таких трубопроводов, например, на участках горячего водоснабжения, позволяет заключить, что они способны выдерживать температуру до $150{ }^{\circ} \mathrm{C}$, при этом вес стеклопластиковых труб в четыре раза меньше стальных (они легко устанавливаются с помощью небольшого подъемного оборудования).

Конструкционные особенности стеклопластиковых трубопроводов и их соединительных элементов позволяют снизить затраты на восстановительные работы, которые не требуют сложного и специального оборудования.

Гидравлические испытания, проведенные зарубежными специалистами, подтверждают тео-
Fig. 1. Fiberglass pipe of large diameter

The experience of laying and constructing this type of pipelines, for example, in the areas of hot water supply allows concluding that they are able to withstand the temperatures of up to $150{ }^{\circ} \mathrm{C}$, while their weight is four times less than the weight of steel pipes (they are easily installed with the help of small lifting equipment).

The design features of fiberglass pipelines and their join elements allow reducing the costs for renovation, that doesn't require complicated and special equipment. 
рию о том, что стеклопластиковая труба имеет высокие прочностные характеристики и устойчивость в системах холодного и горячего водоснабжения. Рабочий диапазон давлений составляет 10 атм и более $[6,7]$.

Необходимо отметить, что применение стеклопластиковых труб позволяет снизить издержки на эксплуатацию сети, так как эти трубы не подвержены коррозии, а также зарастаниям внутренней поверхности, так как имеют низкий уровень шероховатости, который, например, для стали составляет 0,013 , а для стеклопластиков 0,01 [8-15]. Таким образом, не нужно наносить защитные антикоррозионные покрытия и обеспечивать дорогую защиту от электрохимической коррозии.

Трубопроводы из стеклопластиковых труб могут проектироваться подземными, наземными с отсыпкой насыпи или надземными на опорах. Можно комбинировать данные варианты (рис. 2) [16].
Hydraulic tests carried out by foreign specialists confirm the theory that fiberglass pipe has high strength properties and stability in the systems of cold and hot water supply. The operating pressure range is $10 \mathrm{~atm}$ and more [6,7].

It should be noted that the use of fiberglass pipes helps to reduce the costs of system operation, because this type of piping is not subject to corrosion and encrustation of the inner surface, since it has a low level of roughness, which, for example, is 0.013 for a steel pipe, and 0.01 for fiberglass pipe [8-15]. Thus, it is not necessary to put protective corrosion-resistant coatings and to provide an expensive protection against electrochemical corrosion.

Piping made of fiberglass pipes can be designed as underground, aboveground with stacking or raised on poles. It is possible to combine these options (fig. 2) [16].

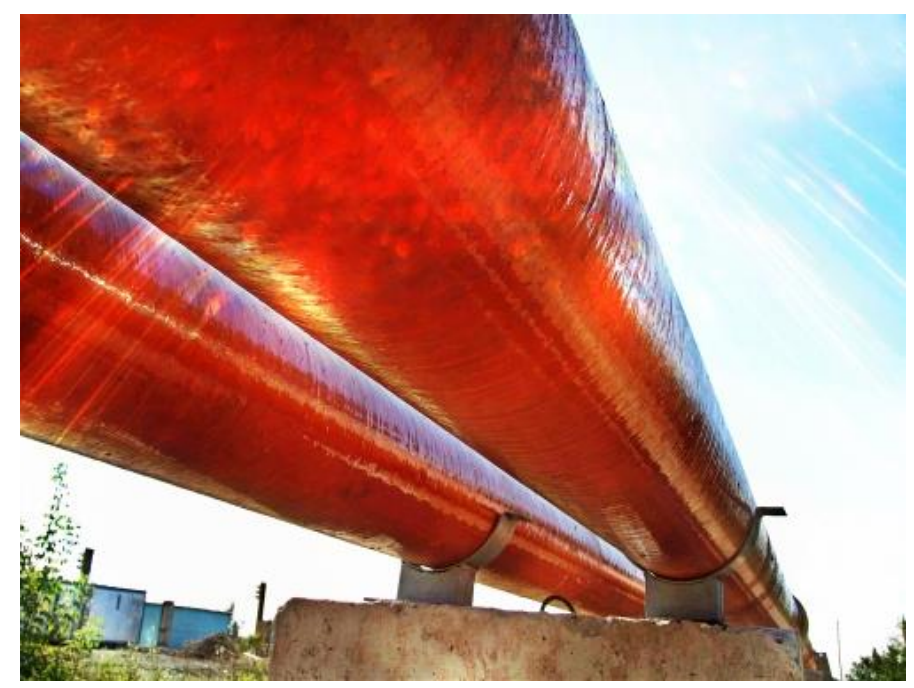

Рис. 2. Стеклопластиковые трубы, проложенные на опорах

Полезным свойством такого типа труб является пониженный расход теплоизоляционного материала, так как стеклопластик обладает низкой теплопроводностью.

Стеклопластиковые трубопроводы способны обеспечить длительную эксплуатацию в различных климатических условиях, поскольку обеспечивают долгую атмосферостойкость.

Таким образом, заявленный нормативный срок службы (ресурс) стеклопластиковых трубопроводов должен составлять не менее 50 лет.

Стеклопластиковые трубопроводы могут изготавливаться многослойными. Стенка трубопро-
Fig. 2. Fiberglass pipes on poles

Such piping has a useful feature - a reduced consumption of heat-insulating material, because fiberglass has a low conductivity.

Fiberglass piping may operate for long in different climatic conditions, because they provide long weathering stability.

So the specified standard service life of fiberglass piping should be not less than 50 years.

The fiberglass pipelines may be produced as multilayered. A pipeline wall, 
вода, которая выполняется из полиэфирного стеклопластика, состоит из трех слоев, характеристики которых приведены ниже.

Первый слой - предназначен обеспечивать герметичность изделия и стойкость к воздействию жидкости в трубе (агрессивная среда).

Второй слой - силовой. Его задача заключается в обеспечении механической прочности трубопровода при комплексном воздействии на него внутренних и внешних нагрузок.

Третий слой - обеспечивает стойкость трубопровода к воздействию неблагоприятных факторов внешней среды: влаги, агрессивных сред и Т.Д.

Стеклопластиковые трубопроводы хорошо себя зарекомендовали также в химической и нефтяной промышленности, а также при эксплуатации систем орошения.

Стеклопластиковые трубы соединяются между собой с помощью муфты, что обеспечивает простоту монтажа. Не нужны сварка и конечный контроль. Это дает значительную экономию затрат на монтажные работы. Также возможны и другие виды соединений, например, муфтовоклеевые, раструбно-клеевые и др.

Необходимо отметить, что в связи с ростом цены на нефть пластмассовые трубопроводы начинают так же подниматься в цене. Себестоимость стекловолокна от этих скачков мало зависит.

Стеклопластиковые трубопроводы являются практически идеальными при использовании бестраншейных технологий восстановления старых трубопроводов $[17,18]$. Например, они рекомендуются в микротоннелировании, которое применяется для прокладки коммуникаций и трубопроводов с помощью коллекторов небольших диаметров в грунте любой сложности, включая песчаные и скальные породы.

Прокладка стеклопластиковых труб методом микротоннелирования или бестраншейным методом осуществляется на глубине до 5 м и на расстояния до 50 м с использованием пневмопробойника, а на глубину до 8 м и на расстояния до 1,5 км с применением микрощитов.

Трубопроводы из стеклопластика применяются для санации бетонных канализационных коллекторов и переходов под железными и автомобильными дорогами. Стеклопластиковая труба используется также при прокладке в футляре под автомобильными дорогами путем центрирования «труба в трубе» (например, на скользящих или лотковых опорах) и под железными дорогами пу- which is produced of polyester glass, consists of three layers, the characteristics of which are listed below.

The first layer is intended to provide integrity of a product and resistance to the influence of a liquid in the pipe (aggressive media).

The second layer is a load-carrying. Its purpose is to provide the mechanical stability of the pipeline at complex inner and outer loads.

The third layer provides pipeline resistance to the unfavorable factors of the outer medium: humidity, aggressive media, etc.

Fiberglass pipelines also showed good results in chemical and oil industry and in irrigation systems.

The fiberglass pipes are connected with the help of coupling, which provides the ease of installation. There is no need in welding and final control. This saves a lot during installation operations. Other variants of joints are also possible, for example, coupling-clay, bell and spigot-clay and other.

It is important to note that because of oil price increase the plastic pipelines are also beginning to rise in price. The production cost of fiberglass barely depends on these leaps.

Fiberglass pipelines are almost ideal in case of trenchless technologies use of old pipelines reconstruction [17, 18]. For example they are recommended in microtunneling, which is used for laying utilities and pipelines with the help of collectors of small diameters in the soil of any complexity including sand and rock materials.

Fiberglass pipelines are laid using microtunneling or trenchless method at the depth of up to $5 \mathrm{~m}$ and at the distance of up to $50 \mathrm{~m}$ using pneumodrift, or at the depth of up to $8 \mathrm{~m}$ at the distance of up to $1,5 \mathrm{~km}$ using microshields.

Fiberglass pipelines are used for sliplining of concrete collecting pipes and tunnels under railways and motorways. Fiberglass pipe is also used at laying in encasement pipes under motor roads by centering "pipe in a pipe" (for example on sliding or tray supports) and under rail- 
тем полной цементации межтрубного пространства. При прокладке стеклопластиковых труб в стальных футлярах или санации необходимо разрабатывать проект крепления труб для каждого проекта индивидуально (рис. 3). лирования

Параметры труб из стеклопластика для микротонне- ways by full cementing of intertube space. In is necessary to develop a piping connection project at laying fiberglass pipes in steel pipes or at sliplining for each project separately (fig. 3). tunneling

The parameters of fiberglass pipes for micro-

\begin{tabular}{|c|c|c|c|c|c|}
\hline \multicolumn{2}{|c|}{$\begin{array}{l}\text { Диаметр трубы, мм } \\
\text { Pipe diameter, mm }\end{array}$} & \multirow{2}{*}{$\begin{array}{c}\text { Толщина стенки } \\
\text { трубы, мм } \\
\text { Wall thickness } \\
\text { of a pipe, mm }\end{array}$} & \multirow{2}{*}{ 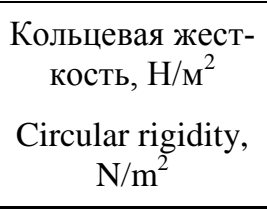 } & \multirow{2}{*}{$\begin{array}{c}\text { Максимальное осевое } \\
\text { усилие, кH } \\
\text { Maximal axial load, kN }\end{array}$} & \multirow{2}{*}{$\begin{array}{c}\text { Macca, } \\
\kappa \Gamma / \mathrm{M} \\
\text { Mass, } \\
\mathrm{kg} / \mathrm{m}\end{array}$} \\
\hline $\begin{array}{c}\text { Наружный } \\
\text { Outer }\end{array}$ & $\begin{array}{c}\text { Внутренний } \\
\text { Inner } \\
\end{array}$ & & & & \\
\hline 564 & 500 & 32 & \multirow{4}{*}{50000} & 703 & 115 \\
\hline 664 & 600 & 32 & & 964 & 138 \\
\hline 776 & 700 & 38 & & 1337 & 192 \\
\hline 876 & 800 & 38 & & 1670 & 219 \\
\hline 1090 & 1000 & 45 & \multirow{5}{*}{64000} & 2450 & 321 \\
\hline 1304 & 1200 & 52 & & 3487 & 441 \\
\hline 1520 & 1400 & 60 & & 4822 & 596 \\
\hline 1736 & 1600 & 68 & & 6054 & 775 \\
\hline 1960 & 1800 & 80 & & 9000 & 1099 \\
\hline 2184 & 2000 & 92 & 80000 & 13833 & 1825 \\
\hline
\end{tabular}

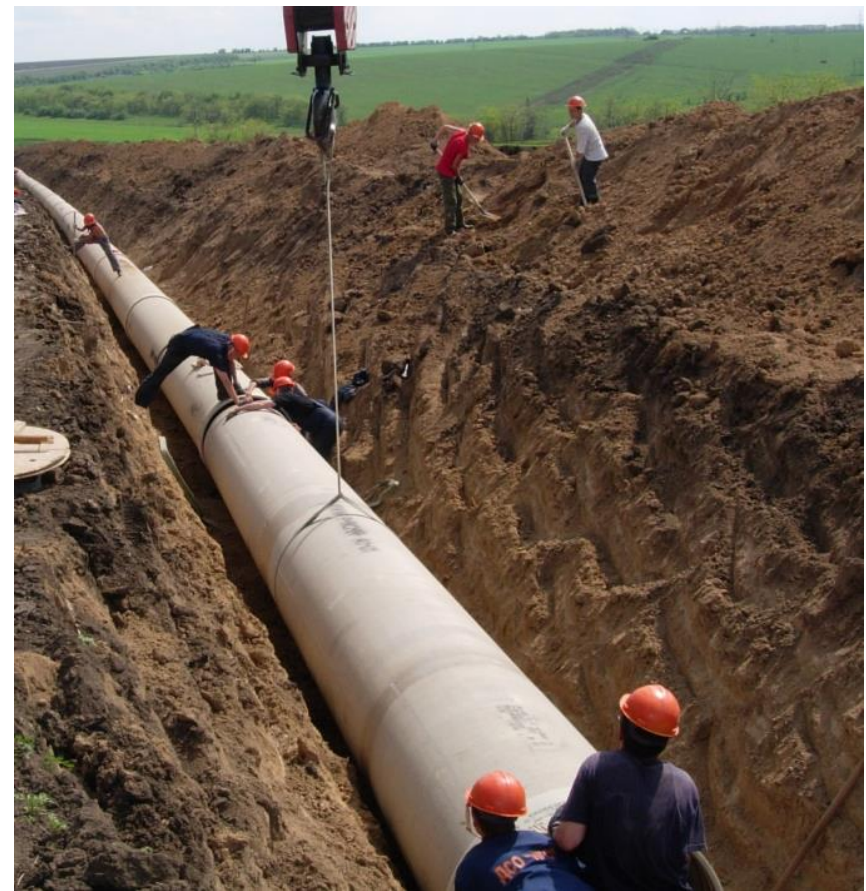

Рис. 3. Открытая прокладка стеклопластиковой трубы большого диаметра

В случае каких-либо повреждений трубопроводов, их можно ремонтировать при помощи специального ремонтного материала, который изготавливается на основе композиционных полимерных покрытий и стеклоткани, что позволяет выдерживать высокие давления.

Была доказана высокая сейсмостойкость стеклопластиковых трубопроводов по сравне-
Fig. 3. Open laying of a fiberglass pipe of a large diameter

In case of any pipelines damage they can be repaired using special repair material produced basing on composite polymer coatings and glass-cloth, which allows resisting high pressures.

The high seismic resistance of fiberglass pipes was proved compared with, for example, concrete ones. They possess the 
нию, например, с бетонными. Они обладают необходимой гибкостью и не трескаются при смещении, а изменяют форму. При деформации почвы в 1 \% стеклопластиковая труба будет в безопасности и покажет хорошую сейсмоустойчивость (при сильном землетрясении интенсивностью 9 баллов) $[19,20]$.

Стеклопластиковые трубопроводы могут спокойно подсоединяться к трубам, выполненным из других материалов. Способ соединения с существующим трубопроводом будет зависеть от того, как проложен и смонтирован существующий трубопровод. Это возможно осуществить или через тройник, или патрубок-накладку. При переходе со стеклопластикового трубопровода на трубопровод из другого материала используется специальный переходной фитинг.

Стеклопластиковые трубы при складировании хранятся на деревянных перекладинах или поддонах с ровной поверхностью. Необходимо обеспечить возможность зацепки изделий стропами для дальнейшего перемещения и подъема в пространстве (рис. 4). necessary flexibility and don't crack at displacements, but change their shape. At soil deformation on $1 \%$ a fiberglass pipe will be safe and will display good seismic resistance (in case of a strong earthquake of the intensity scale of $9[19,20]$.

Fiberglass Pipes may be connected to the pipes made of other materials. The method of connection with the existing pipeline will depend on how the existing pipeline is laid and constructed. It is possible to be made via T-socket or spigot paddle. When changing from fiberglass pipeline to a pipeline made of another material special reducing fitting is used.

When storing fiberglass pipelines are kept on wooden beams or trays with even surface. It is necessary to provide the possibility to hook them with slings for further movement and raise (fig. 4).

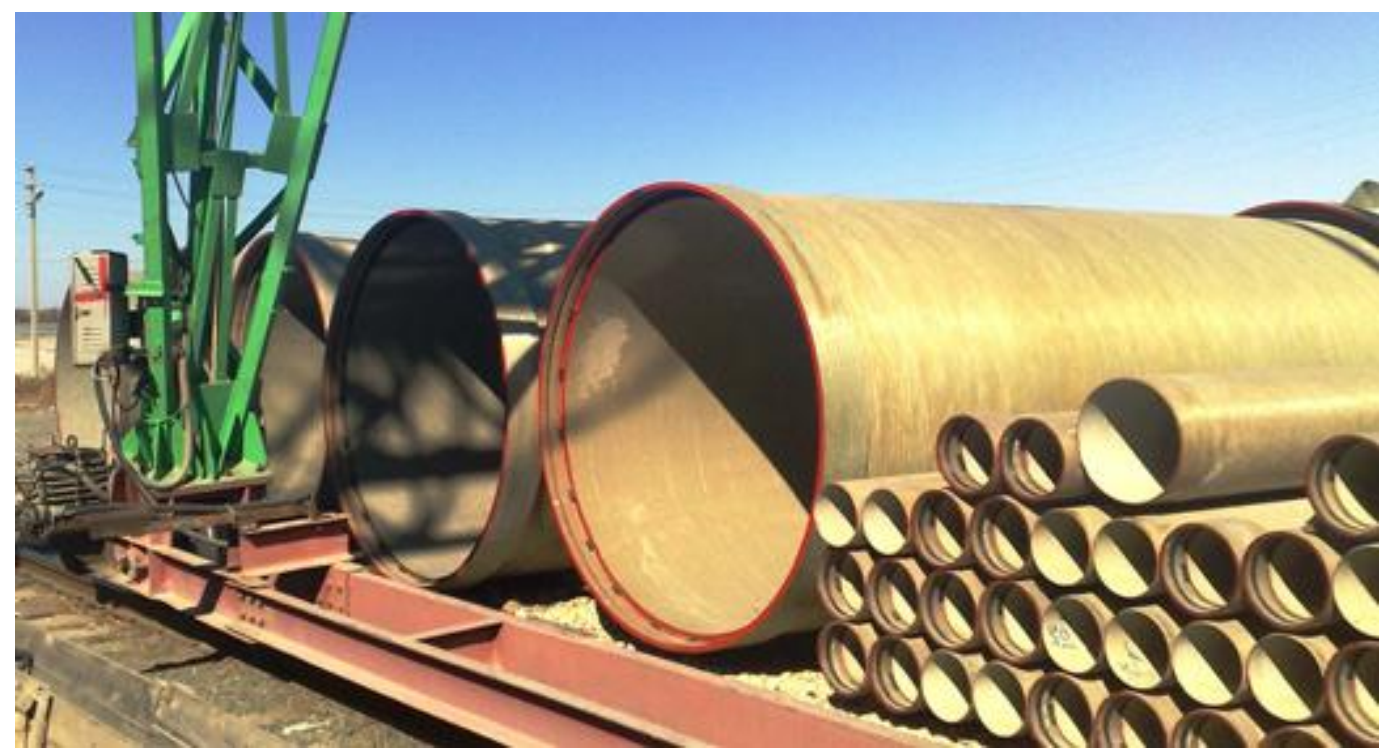

Рис. 4. Перемещение стеклопластиковых труб с железнодорожного состава

Bblвод. Несмотря на достоинства данных трубопроводов, их применение в нашей стране ограничено, прежде всего, в районах крайнего севера, так как там отсутствует научнообоснованная стратегия и технология строительства на вечномерзлых грунтах. Также высокая цена и необходимость закупок иностранных комплектующих делают применение данной продукции ограниченным.
Fig. 4. Transfer of fiberglass pipelines from a rail transport

In conclusion we can note the following. Despite the advantages of such pipelines their use in our country is limited, first of all, in Extreme Northern areas, because there is no scientifically proved strategy and technology of construction on permafrost soil. Also their use is limited because of the high price and the necessity to buy foreign components. 


\section{БИБЛИОГРАФИЧЕСКИЙ СПИСОК}

1. Орлов В.А., Михайлин А.В., Орлов Е.В. Технологии бестраншейной реновации трубопроводов. М. : Изд-во АСВ, 2011. 135 с.

2. Отставнов А.А., Хантаев И.С., Орлов E.B. К выбору труб для бестраншейного устройства трубопроводов водоснабжения и водоотведения // Пластические массы. 2007. № 3. С. $40-43$.

3. Орлов Е.В., Квитка Л.А., Михайлин А.В., Кудряшова Г.Н., Комаров А.С., Юнчина М.Н. К выбору трубопроводов для систем водопровода специального назначения // Естественные и технические науки. 2015. № 2 (80). C. $154-155$.

4. Zwierzchowska A. Technologie bezwykopowej budowy sieci gazowych, wodociagowych i kanalizacyjnych. Kielce : Politechnika Swietokrzyska, 2006. $180 \mathrm{~s}$.

5. Rameil M. Handbook of pipe bursting practice. Essen : Vulkan verlag, 2007. 351 p.

6. Kuliczkowski A., Kuliczkowska E. Zwierzchowska A. Technologie beswykopowe w inzeynierii srodowiska. Kielce : Wydawnictwo Seidel-Przywecki Sp, 2010. 735 s.

7. Орлов Е.В., Мельников Ф.А., Се ров А.Е., Аксенова Н.В., Балавас М.Я. Трубопроводы временного назначения. Эксплуатация на строительных площадках для удаления отходов // Техника и технологии мира. 2015. № 2. С. $29-32$.

8. Андрианов А.П., Бастрыкин Р.И., Чухин B.A. Изучение коррозионных отложений в трубопроводах систем подачи и распределения питьевой воды // Водоснабжение и санитарная техника. 2013. № 7. С. 30-36.

9. Чухин В.А., Андрианов А.П. О возможности идентификации биокоррозии в системах водоснабжения // Водоснабжение и санитарная техника. 2015. № 5. С. $32-41$.

10. Чухин В.А., Андрианов А.П. Морфология ржавчины: Особенности коррозии трубопроводов в системах водоснабжения // Вода Magazine. 2013. № 5 (69). С. 42-44.

11. Андрианов А.П., Чухин В.А. Структурные и морфологические особенности коррозии стальных водопроводных труб // Научное обозрение. 2014. № 7 (1). С. 176-180.

12. Андрианов А.П., Орлов В.А., Чухин В.А., Серова Е.М., Неверова М.А. Коррозия трубопроводов и мероприятия по ее локализации // Вестник Иркутского государственного технического университета. 2014. № 8 (91). C. $74-78$.

13. Отставнов А.А., Орлов Е.В., Хантаев И.С. Определение приоритетных участков ремонта систем водоснабжения и водоотведения // Водоснабжение и санитарная техника. 2007. № 3. С. $25-30$.

14. Орлов В.А., Орлов Е.В. Остаточный ресурс напорных стальных трубопроводов систем водоотведения // Вестник МГСУ. 2008. № 4. С. $122-127$.

\section{REFERENCES}

1. Orlov V.A., Mikhaylin A.V., Orlov E.V. Tekhnologii bestransheynoy renovatsii truboprovodov [Technology of Trenchless Rehabilitation of Pipelines]. Moscow, ASV Publ., 2011, 135 p. (In Russian)

2. Otstavnov A.A., Khantaev I.S., Orlov E.V. K vyboru trub dlya bestransheynogo ustroystva truboprovodov vodosnabzheniya i vodootvedeniya [Choosing Pipes for Construction of Trenchless Piping of Water Supply and Sanitation]. Plasticheskie massy [Plastic Pipes]. 2007, no. 3, pp. 40-43. (In Russian)

3. Orlov E.V., Kvitka L.A., Mikhaylin A.V., Kudryashova G.N., Komarov A.S., Yunchina M.N. K vyboru truboprovodov dlya sistem vodoprovoda spetsial'nogo naznacheniya [Choosing Piping for Plumbing Systems for Special Purposes]. Estestvennye $i$ tekhnicheskie nauki [Natural and Technical Sciences]. 2015, no. 2 (80), pp. 154-155. (In Russian)

4. Zwierzchowska A. Technologie bezwykopowej budowy sieci gazowych, wodociagowych i kanalizacyjnych. Kielce, Politechnika Swietokrzyska, 2006, 180 p.

5. Rameil M. Handbook of Pipe Bursting Practice. Essen, Vulkan verlag, 2007, 351 p.

6. Kuliczkowski A., Kuliczkowska E., Zwierzchowska A. Technologie beswykopowe w inzeynierii srodowiska. Kielce, Wydawnictwo Seidel-Przywecki Sp, 2010, 735 p.

7. Orlov E.V., Mel'nikov F.A., Serov A.E., Aksenova N.V., Balavas M.Ya. Truboprovody vremennogo naznacheniya. Ekspluatatsiya na stroitel'nykh ploshchadkakh dlya udaleniya otkhodov [Pipelines of Temporary Purpose. Operation on Construction Sites for Waste Management]. Tekhnika i tekhnologii mira [Equipment and Technologies of the World]. 2015, no. 2, pp. 29-32. (In Russian)

8. Andrianov A.P., Bastrykin R.I., Chukhin V.A. Izuchenie korrozionnykh otlozheniy $\mathrm{v}$ truboprovodakh sistem podachi raspredeleniya pit'evoy vody [Study of Corrosive Sediments in the Piping Systems for Supply and Distribution of Drinking Water]. Vodosnabzhenie i sanitarnaya tekhnika [Water Supply and Sanitary Technique]. 2013, no. 7, pp. 30-36. (In Russian)

9. Chukhin V.A., Andrianov A.P. O vozmozhnosti identifikatsii biokorrozii v sistemakh vodosnabzheniya [On the Possibilities of Bio-Corrosion Identification in Water Supply Systems]. Vodosnabzhenie i sanitarnaya tekhnika [Water Supply and Sanitary Technique]. 2015, no. 5, pp. 32-41. (In Russian)

10. Chukhin V.A., Andrianov A.P. Morfologiya rzhavchiny: Osobennosti korrozii truboprovodov v sistemakh vodosnabzheniya [Morphology of Rust: Features of Pipeline Corrosion in Water Supply Systems]. Voda Magazine. 2013, no. 5 (69), pp. 42-44. (In Russian)

11. Andrianov A.P., Chukhin V.A. Strukturnye i morfologicheskie osobennosti korrozii stal'nykh vodoprovodnykh trub [Structural and Morphological Features of Corrosion of Steel Water Pipes]. Nauchnoe obozrenie [Scientific Review]. 2014, no. 7 (1), pp. 176-180. (In Russian)

12. Andrianov A.P., Orlov V.A., Chukhin V.A., Serova E.M., Neverova M.A. Korroziya truboprovodov i meropriyatiya po ee lokalizatsii [Corrosion of Pipelines and Measure of Its Localization]. Vestnik Irkutskogo gosudarstvennogo tekhnicheskogo universiteta [Proceedings of Irkutsk National Research Technical University]. 2014, no. 8 (91), pp. 74-78. (In Russian)

13. Otstavnov A.A., Orlov E.V., Khantaev I.S. Opredelenie prioritetnykh uchastkov remonta sistem vodosnabzheniya i vodootvedeniya [Determining the Priority Areas of Water Supply and Sanitation Systems for Repair]. Vodosnabzhenie i sanitarnaya tekhnika [Water Supply and Sanitary Technique]. 2007, no. 3, pp. 25-30. (In Russian) 
15. Орлов В.А., Орлов Е.В., Зверев П.В. Технологии местного бестраншейного ремонта водоотводящих трубопроводов // Вестник МГСУ. 2013. № 7. С. 86-95.

16. Zwierzchowska A. Optymalizacja doboru metod bezwykopowej budowy. Kielce : Politechnika Swietokrzyska, 2003. 160 s.

17. Отставнов А.А., Орлов Е.В., Хантаев И.С. Первоочередность восстановления трубопроводов водоснабжения и водоотведения // Строительный инжиниринг. 2007. № 10. C. $44-49$.

18. Орлов В.А., Хантаев Е.С., Орлов Е.В. Влияние дестабилизирующих факторов на работоспособность водоотводящих сетей урбанизированных территорий // Экология урбанизированных территорий. 2007. № 3. С. $43-51$.

19. Мкртычев О.В., Андреева П.И. Проблема построения спектров с заданной обеспеченностью при расчете на землетрясения // International Journal for Computational Civil and Structural Engineering. 2014. Vol. 10. No. 2. Pp. $102-104$.

20. Yang F., Shi B., Gu J., Wang D., Yang M. Morphological and physicochemical characteristics of iron corrosion scales formed under different water source histories in a drinking water distribution system // Water Research. 2012. Vol. 46. No. 16. Pp. 5423-5433.

Поступила в редакцию в июне 2015 2.
14. Orlov V.A., Orlov E.V. Ostatochnyy resurs napornykh stal'nykh truboprovodov sistem vodootvedeniya [Residual Life of Pressure Steel Pipelines of Water Disposal Systems]. Vestnik $M G S U$ [Proceedings of Moscow State University of Civil Engineering]. 2008, no. 4, pp. 122-127. (In Russian)

15. Orlov V.A., Orlov E.V., Zverev P.V. Tekhnologii mestnogo bestransheynogo remonta vodootvodyashchikh truboprovodov [Technology for Sectional Trenchless Repair of Water Discharge Pipelines]. Vestnik MGSU [Proceedings of Moscow State University of Civil Engineering]. 2013, no. 7, pp. 86-95. (In Russian)

16. Zwierzchowska A. Optymalizacja doboru metod bezwykopowej budowy. Kielce, Politechnika Swietokrzyska, 2003, $160 \mathrm{p}$.

17. Otstavnov A.A., Orlov E.V., Khantaev I.S. Pervoocherednost' vosstanovleniya truboprovodov vodosnabzheniya i vodootvedeniya [Priority Rehabilitation of Water Supply and Sanitation Pipelines]. Stroitel'nyy inzhiniring [Construction Engineering]. 2007, no. 10, pp. 44-49. (In Russian)

18. Orlov V.A., Khantaev E.S., Orlov E.V. Vliyanie destabiliziruyushchikh faktorov na rabotosposobnost' vodootvodyashchikh setey urbanizirovannykh territoriy [Influence of Destabilizing Factors on the Performance of Drainage Networks in Urbanized Areas]. Ekologiya urbanizirovannykh territoriy [Ecology of Urban Areas]. 2007, no. 3, pp. 43-51. (In Russian)

19. Mkrtychev O.V., Andreeva P.I. Problema postroeniya spektrov s zadannoy obespechennost'yu pri raschete na zemletryaseniya [The Problem of Constructing Spectra with a Given Security when Calculating Earthquakes]. International Journal for Computational Civil and Structural Engineering. 2014, vol. 10, no. 2, pp. 102-104. (In Russian)

20. Yang F., Shi B., Gu J., Wang D., Yang M. Morphological and Physicochemical Characteristics of Iron Corrosion Scales Formed under Different Water Source Histories in a Drinking Water Distribution System. Water Research. 2012, vol. 46, no. 16, pp. 5423-5433. DOI: http://dx.doi.org/10.1016/j.watres.2012.07.031.

Received in June 2015.
О б ав торах: Никитина Ирина Николаевна, инженер, заведующая лабораторией кафедры водоснабжения, Национальный исследовательский Московский государственный строительный университет (НИУ МГСУ), 129337, г. Москва, Ярославское шоссе, д. 26, 8 (499) 183-36-29, tmre2014@yandex.ru;

Еремеев Александр Владимирович, студент Института инженерно-экологического строительства и механизации, Национальный исследовательский Московский государственный строительный университет (НИУ МГСУ), 129337, г. Москва, Ярославское шоссе, д. 26, 8 (499) 183-36-29, tmre2014@yandex.ru.
A bout the authors: Nikitina Irina Nikolaevna, engineer, head of the laboratory, Department of Water Supply, Moscow State University of Civil Engineering (National Research University) (MGSU), 26 Yaroslavskoe shosse, Moscow, 129337, Russian Federation; +7 (499) 183-36-29; tm-re2014@yandex.ru;

Eremeev Aleksandr Vladimirovich, student, Institute of Engineering and Ecological Construction and Mechanization, Moscow State University of Civil Engineering (National Research University) (MGSU), 26 Yaroslavskoe shosse, Moscow, 129337, Russian Federation; +7 (499) 183-36-29; tm-re2014@yandex.ru.

\section{Для цитирования:}

Никитина И.Н., Еремеев А.В. Перспектива применения стеклопластиковых трубопроводов при строительстве и реконструкции инженерных сетей // Строительство: наука и образование. 2015. № 3. Ст. 2. Режим доступа: http://nso-journal.ru.

For citation:

Nikitina I.N., Eremeev A.V. Perspektiva primeneniya stekloplastikovykh truboprovodov pri stroitel'stve i rekonstruktsii inzhenernykh setey [Possibilities of the Use of GRP Piping in the Construction and Reconstruction of Engineering Networks]. Stroitel'stvo: nauka i obrazovanie [Construction: Science and Education]. 2015, no. 3, paper 2. Available at: http://www.nsojournal.ru. (In Russian) 